\title{
Direct correlation of Tithonian/Berriasian boundary calpionellid and calcareous nannofossil events in the frame of magnetostratigraphy: new results from the West Balkan Mts, Bulgaria, and review of existing data
}

\author{
Iskra Lakoval, Jacek Grabowski², Kristalina Stoykova ${ }^{1}$, Silviya Petrova ${ }^{1}$, \\ Daniela Reháková ${ }^{3}$, Katarzyna Sobieńn ${ }^{2}$ Petr Schnabl
}

\author{
${ }^{1}$ Geological Institute, Bulgarian Academy of Sciences, Acad. G. Bonchev Str., Bl. 24, 1113 Sofia, Bulgaria; \\ e-mails:lakova@geology.bas.bg, silviya_p@geology.bas.bg, stoykova@geology.bas.bg \\ ${ }^{2}$ Polish Geological Institute - National Research Institute, Rakowiecka 4, 00-975 Warszawa, Poland, \\ e-mails: jacek.grabowski@pgi.gov.pol,katarzyna.sobien@pgi.gov.pl \\ ${ }^{3}$ Comenius University, Faculty of Natural Sciences, Department of Geology and Palaeontology, Mlynská dolina G-229, \\ Ilkovičova 6, SK-84215 Bratislava, SlovakRepublic; e-mail: daniela.rehakova@uniba.sk \\ ${ }^{4}$ Institute of Geology, Academy of Sciences of the Czech Republic, v.v.l., Rozvojová, 269,165000 Praha 6, Czech Republic; \\ e-mail: schnabl@gli.cas.cz
}

(Accepted in revised form October 2017)

\begin{abstract}
Magnetostratigraphy, calpionellid and calcareous nannofossil biostratigraphy of the upper Tithonian and lower Berriasian of section Barlya in the West Balkan Mts are herein presented. The studied interval comprises the magnetozones from M21r to M17r, with a large interval of partial remagnetization. It has been directly correlated with a continuous succession of the calpionellid Chitinoidella, Praetintinnopsella, Crassicollaria and Calpionella zones, and with the nannofossil zones from NJT 15b to NK-1. The accumulated evidence in the last twenty years on the magnetostratigraphy, calpionellid and calcareous nannofossil biostratigraphy and events across the $\mathrm{J} / \mathrm{K}$ boundary in the European Tethys has provoked the authors to plot the main micropalaeontological events against magnetostratigraphic column in order to assess the extent of diachronism of these events. Data from Slovakia, Poland, Italy, Austria, Hungary, France, Spain and Bulgaria has shown specific behaviour of different calpionellid and nannofossil events with respect to the column of the magnetic polarity chrons, which have been considered as 'isochronous' or at least less diachronous than the microfossil events. Thus, some rather consistent events have appeared, such as the first occurrences (FOs) of calpionellids Calpionella grandalpina, Crassicollaria brevis, Calpionella minuta and Remaniella ferasini, and the FOs of calcareous nannofossils Nannoconus globulus minor, Hexalithus geometricus, Nannoconus wintereri, Nannoconus steinmannii minor and Nannoconus kamptneri minor. The J/K boundary, as widely accepted, has been traced in section Barlya at the base of the Calpionella alpina Subzone.
\end{abstract}

Lakova, I., Grabowski, J., Stoykova, K., Petrova, S., Reháková, D., Sobień, K., Schnabl, P. 2017. Direct correlation of Tithonian/Berriasian boundary calpionellid and calcareous nannofossil events in the frame of magnetostratigraphy: new results from the West Balkan Mts, Bulgaria, and review of existing data. Geologica Balcanica 46 (2), 47-56.

Keywords: calpionellids, calcareous nannofossils, magnetostratigraphy, J/K boundary, West Balkan Mts, Bulgaria, Tethyan Realm.

\section{INTRODUCTION}

The present micropalaeontological study of the calpionellid (Iskra Lakova and Silviya Petrova) and calcareous nannofossil (Kristalina Stoykova) vertical distribution and recognition of certain events is restricted to the upper Tithonian and lower Berriasian (from the base of the Chitinoidella Zone to the base of the Elliptica Subzone of the Calpionella Zone) (Fig. 1).
Actually, the lowermost part of the studied interval in section Barlya, i.e., the Dobeni Subzone of the Chitinoidella Zone, should be assigned to the topmost lower Tithonian (see Benzaggagh et al., 2010; Gradstein et al., 2012). The calpionellid and nannofossil events have been directly confronted to magnetostratigraphy (Jacek Grabowski, Katarzyna Sobień, and Petr Schnabl). The plotting of calpionellid events versus magnetostratigraphy (Iskra Lakova and Daniela Re- 


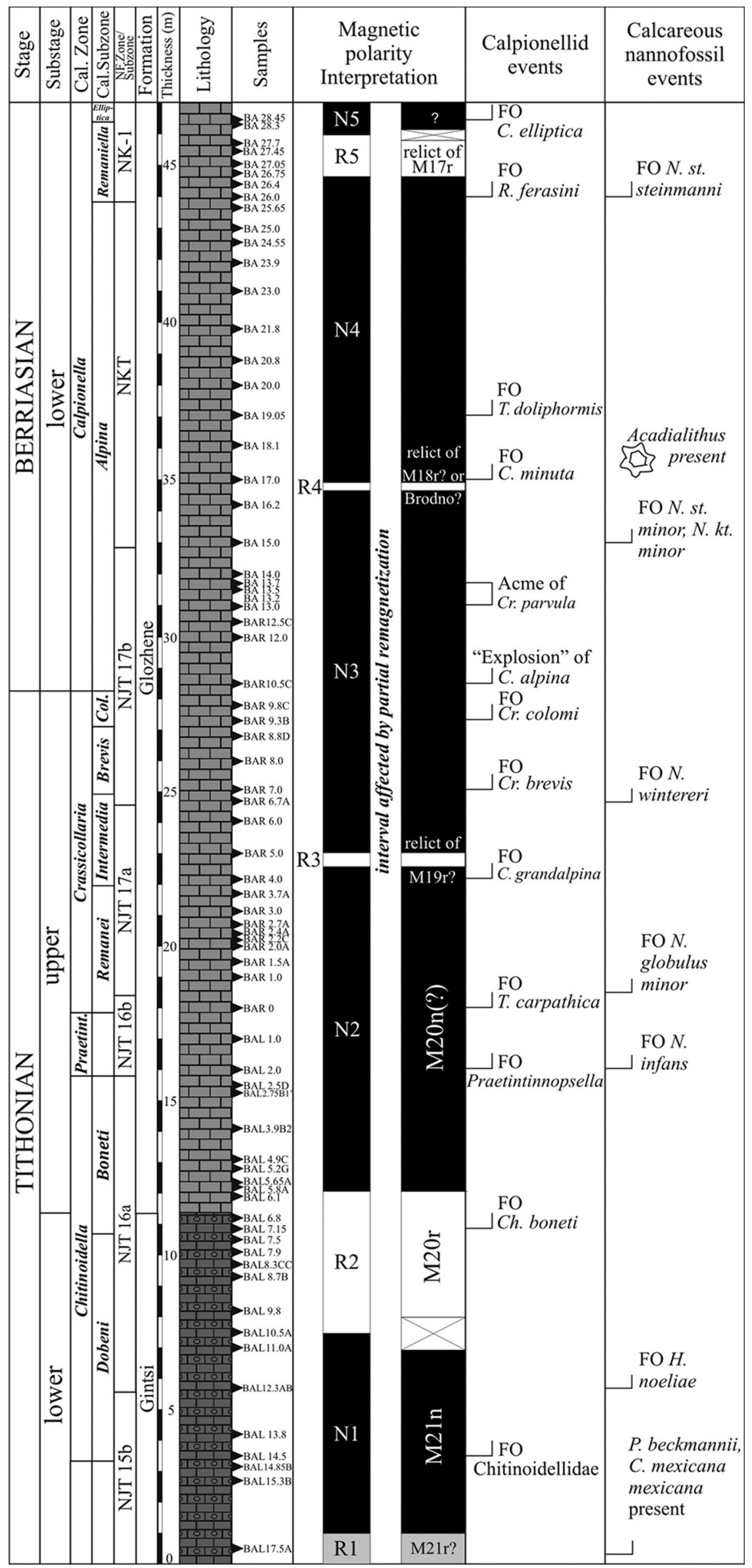


Fig. 1. The upper Tithonian and lower Berriasian of section Barlya: magnetostratigraphy, calpionellid events and biostratigraphy, and calcareous nannofossil events and biostratigraphy (calpionellid zonation scheme according to Reháková and Michalík, 1997; Pop, 1997; and Lakova and Petrova, 2013; nannofossil zonation scheme according to Casellato, 2010). Black - normal polarity; white - reversed polarity; grey - reversed polarity interpreted from great circle demagnetization paths.

háková) and the nannofossil events versus magnetostratigraphy (Kristalina Stoykova) of practically all published sections across the Tithonian/Berriasian boundary seem very promising for estimation of how consistent and reliable for distant correlation the main microfossil events are. Since this review is restricted to the European Tethys, remote localities with magneto- and calpionellid biostratigraphy such as that in Argentina (Kietzmann, 2017; Iglesia Llanos et al., 2017) still remain outside the geographic scope of this account.

The Upper Berriasian part of section Barlya has already been published, involving palaeomagnetism, calpionellid and nannofossil biostratigraphy (Grabowski et al., 2016). The last reviews of the microfossil biostratigraphy and/or magnetostratigraphy (Michalík and Reháková, 2011; Grabowski, 2011) of the Jurassic/Cretaceous $(\mathrm{J} / \mathrm{K})$ boundary strata were followed by study of additional sections in the European Tethys, which deserve to be incorporated in the present review. The purposes of this publication are: 1) to present new results on the direct calibration of magnetostratigraphy and calpionellid and calcareous nannofossil biostratigraphy of the upper Tithonian and lower Berriasian in the continuous section Barlya in the West Balkan Mts in Bulgaria; and 2) to determine the extent of diachroneity and dispersion of certain key calpionellid and nannofossil events with respect to magnetostratigraphy.

\section{MATERIAL AND METHODS}

A total of 160 oriented cores were drilled from the Tithonian-lower Berriasian interval of the Barlya section. Sampling resolution was between $0.1 \mathrm{~m}$ and $0.5 \mathrm{~m}$. One to three standard palaeomagnetic specimens (25.4 $\mathrm{mm}$ diameter, $22 \mathrm{~mm}$ length) were prepared from each core. The palaeomagnetic experiments were carried out in the Paleomagnetic Laboratories of the Institute of Geology (Academy of Sciences of the Czech Republic, Pruhonice, Prague) and in the Polish Geological Institute-National Research Institute (PGI-NRI) in Warsaw. Palaeomagnetic procedure in the Pruhonice Laboratory included a progressive thermal (TH) demagnetization, using the MAVACS (Magnetic Vacuum Control System). The natural re- manent magnetization (NRM) was measured, using the 2G Superconducting Rock Magnetometer 755 (2G SRM). The magnetic susceptibility $(\chi)$ was measured with AGICO KLF-4A Automatic Magnetic Susceptibility Meter after each demagnetizing step. NRM in the laboratory of PGI-NRI was measured with a JR-6A spinner magnetometer (AGICO, Brno; noise level $\left.10^{-5} \mathrm{~A} / \mathrm{m}\right)$. Samples were demagnetised thermally, using the non-magnetic MMTD oven (Magnetic Measurements, UK, rest field $<10 \mathrm{nT}$ ). NRM measurements and demagnetization experiments were carried out in the magnetically shielded space (a lowfield cage, Magnetic Measurements, UK, which reduces the ambient geomagnetic field by about 95\%). Magnetic susceptibility was monitored with a KLY-2 bridge (AGICO, Brno; sensitivity $10^{-8}$ SI units) after each thermal demagnetization step. Characteristic components of magnetization were calculated, using REMASOFT software (Chadima and Hrouda, 2006). Despite the different measurement and demagnetization equipment, the results from both laboratories were fully concordant. Although calpionellid and nannofossil stratigraphy of the Barlya section had been studied before (e.g., Lakova et al., 1999), new sampling and biostratigraphic studies were integrated with the palaeomagnetic investigations presented in this study.

Widely accepted processing of samples (i.e., smear-slides for nannofossils and thin-section observations for calpionellids) was performed, followed by application of classical biostratigraphic methods for detection of bio-events.

\section{RESULTS OF SECTION BARLYA}

\section{Palaeomagnetic results}

NRM intensities were quite strong, usually exceeding $10^{-3} \mathrm{~A} / \mathrm{m}$. Most of the samples revealed presence of three components of magnetization: A, B and C, with well-separated unblocking temperature spectra (Fig. 2). Component A, with unblocking temperatures between $100{ }^{\circ} \mathrm{C}$ and $250{ }^{\circ} \mathrm{C}$, is virtually identical with the present-day geomagnetic field direction (in present-day coordinates). Component B reveals exclusively reversed polarity and it is unblocked between $250{ }^{\circ} \mathrm{C}$ and $350-400{ }^{\circ} \mathrm{C}$. The hardest, predominantly 


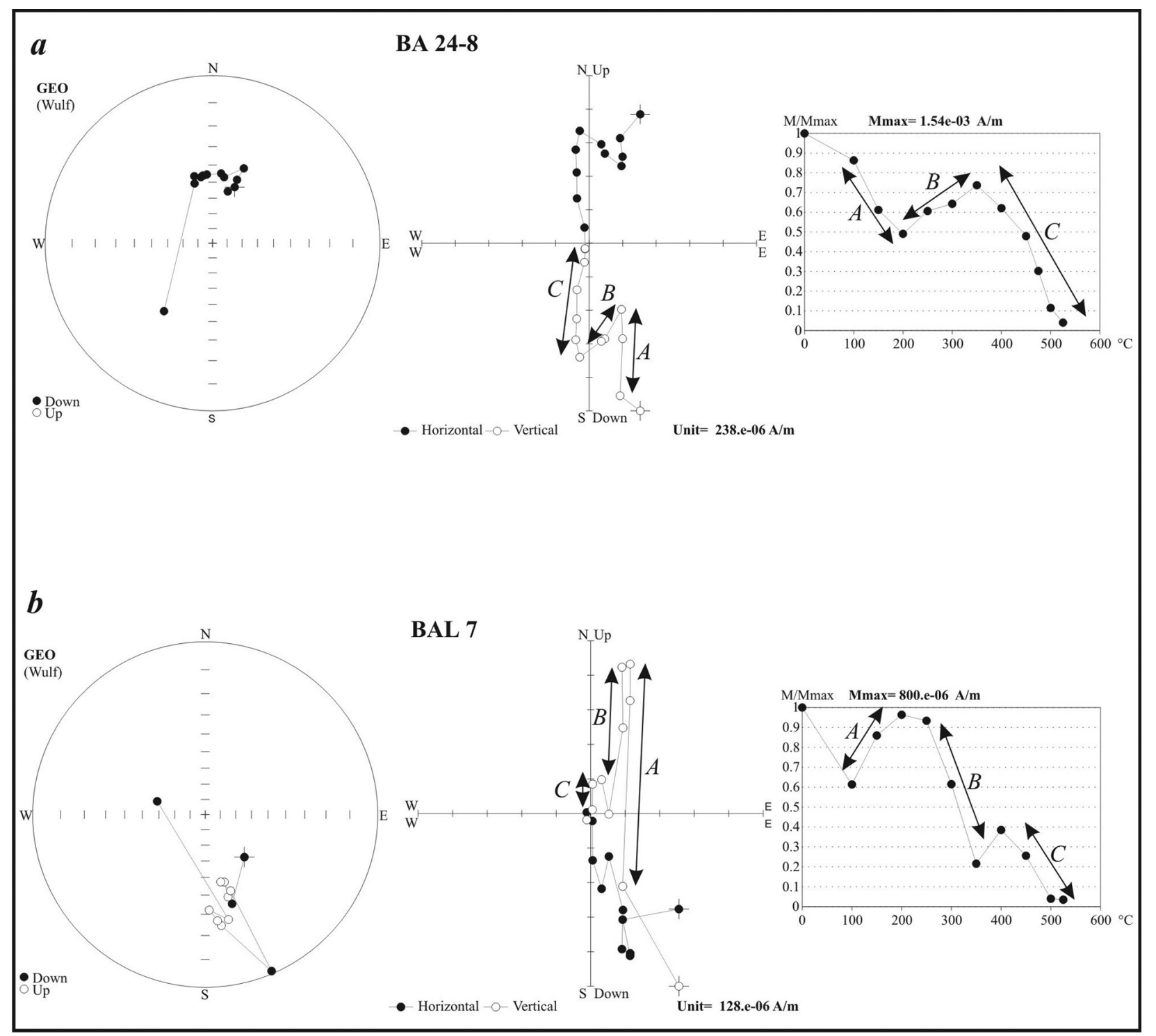

Fig. 2. Thermal demagnetization of typical specimens with normal and reversed component C. a) sample BA 24-8. Interval N4, Alpina Subzone; $b$ ) sample BAL 7, interval R2 (M20r?), Dobeni Subzone. Left - stereographic projection of demagnetization path; middle - orthogonal projection; right - NRM decay during thermal treatment. A, B and C components indicated. All projections are in geographic (in situ) coordinates.

normal, polarity component $\mathrm{C}$ is demagnetized between $400{ }^{\circ} \mathrm{C}$ and $525^{\circ} \mathrm{C}$.

A relatively long interval of reversed polarity is observed between samples BAL 10.5A and BAL 6.1 in the Chitinoidella Zone (interval R2, see Fig. 2b). Short and very short reversed polarity intervals occur between samples BAL 17.3 and BAL 17.15 (below the Chitinoidella Zone, interval R1), BAR 4.7 to BAR 4.8 (interval R3, Intermedia Subzone), in sample BA 16.8 (interval R4, middle part of the Alpina Subzone) and in the topmost part of the section between samples BA 26.75 and BA 27.90 (interval R5, Remaniella Subzone).

\section{Calpionellid biostratigraphy}

\section{Upper Tithonian}

The succession of Tithonian chitinoidellid and calpionellid events involves, from bottom to top, the FOs of Chitinoidellidae, Chitinoidella boneti, Praetintinnopsella andrusovi, Calpionellidae (namely Tintinnopsella carpathica/Tintinnopsella remanei), Calpionella grandalpina, Crassicollaria brevis and Crassicollaria colomi, as well as the last occurrence (LO) of Calpionella elliptalpina. In the upper part of the Crassicollaria Zone, crassicollarians show significant decline. 
The following zones have been documented (Fig. 1): Chitinoidella (with Dobeni and Boneti subzones), Praetintinnopsella and Crassicollaria (with Remanei, Intermedia, Brevis and Colomi subzones).

\section{Lower Berriasian}

The base of the Calpionella Zone is herein considered as the base of the Berriasian, i.e., the $\mathrm{J} / \mathrm{K}$ boundary. The early Berriasian calpionellid events began with the "explosion" of the small spherical Calpionella alpina, followed by acme of Crassicollaria parvula and the successive FOs of Calpionella minuta, Tintinnopsella doliphormis, Remaniella ferasini and Calpionella elliptica. These calpionellid events were used for determination of the base of the Alpina, Remaniella and Elliptica subzones of the Calpionella Zone. The acme of Crassicollaria parvula and the FOs of Calpionella minuta and Tintinnopsella doliphormis appear as auxiliary events that help informal subdivision of the Alpina Subzone.

\section{Calcareous nannofossil biostratigraphy}

The succession of calcareous nannofossil events includes widely recorded FOs in the Tethys, such as that of Hexalithus noeliae, Nannoconus infans, Nannoconus globulus minor, Nannoconus wintereri, the coeval FOs of Nannoconus steinmannii minor and Nannoconus kamptneri minor, and the FO of Nannoconus steinmannii steinmannii. These events define, in ascending order, Casellato's (2010) nannofossil (sub) zones NJT 16a, NJT 16b, NJT 17a, NJT 17b, NKT and NK-1. The base of the Calpionella Zone is within nannofossil subzone NJT 17b (Fig. 1). It is worth mentioning the occurrence of the newly described genus Acadialithus (Acadialithus dennei) in zone NKT (samples BAL 17 and BAL 19.10). Hexalithus geometricus, a species somewhat neglected so far, is of interest since it shows very consistent FO in different Tethyan sections and appears quite close to the base of the Calpionella Zone.

\section{DISCUSSION AND REVIEW OF RECENT DATA}

\section{Interpretation of magnetostratigraphy}

Component $\mathrm{A}$ is interpreted as recent viscuous remanent magnetization. Component $\mathrm{B}$ has already been documented in the upper Berriasian part of the Barlya section (Grabowski et al., 2016) and interpreted as a pre-folding overprint. The nature of component $\mathrm{C}$ is not clear. The succession of normal and reversed intervals of component $\mathrm{C}$ can hardly be correlated with the reference Global Polarity Time Scale for the Tithonian-early Berriasian (Gradstein et al., 2012). Although normal polarity regime of the geomagnetic field in- deed prevailed in the late Tithonian-early Berriasian transition (for review: Ogg et al., 1991; Grabowski, 2011), the position of reversed polarity magnetozones and magnetosubzones is well constrained to calpionellid stratigraphy. Between the base of the Chitinoidella Zone and the base of the Elliptica Subzone, six reversed polarity intervals should be expected: M20r, M20n1r, M19r, M19n1r (Brodno), M18r and M17r. Relatively long reversed interval R2 with the FO of Chitinoidella boneti might be interpreted as M20r, since the Dobeni/Boneti subzonal boundary is typically situated in this magnetozone (e.g., Ogg et al., 1991; Michalík et al., 2009; Grabowski et al., 2010a, b). However, the other five reversed magnetozones could hardly be identified. The thin reversed interval R3 (just above the $\mathrm{FO}$ of Calpionella grandalpina) might be interpreted as M19r (see, e.g., Michalík et al., 2009, 2016). The reversed interval R4, below the FO of Calpionella minuta, might be either M19n1r (Brodno) or M18r (see, e.g., Pruner et al., 2010). Both of these intervals are extremely thin. That stays in contrast with typical development of these magnetozones. Usually, even in condensed sections, with sedimentation rate of 1-4 m/Myr, the M19r and M18r have been well recorded and thin reversed magnetosubzones have been documented as well (Michalík et al., 2009; Pruner et al., 2010; Grabowski et al., 2010a). Surprisingly, the base of the Elliptica Subzone in section Barlya falls in the normal polarity interval N5, which is not typical since this bioevent usually occurs in the long reversed polarity magnetozone M17r (Channell and Grandesso, 1987; Grabowski and Pszczółkowski, 2006; Michalík et al., 2016). These observations indicate that the magnetostratigraphic record in the Barlya section is either incomplete (lacking large parts of reversed magnetozones) or the section has been partially remagnetized. As the Barlya section is excellently exposed, with very gentle tectonic deformations (monoclinal dip, no internal faults or overthrusts) and no visible sedimentary breaks (breccia levels, hardground horizons), the remagnetization hypothesis seems more likely. Remagnetization must have been not complete, and that is why the "relicts" of reversed magnetozones were preserved. The question why the Tithonian-lower Berriasian part of the Barlya section is partially remagnetized whilst in the upper Berriasian interval primary magnetization was preserved (Grabowski et al., 2016) cannot be answered for the time being. Further investigations will focus on comparison of rock magnetic properties of both remagnetized and unremagnetized parts of the section and constraining the timing and origin of the remagnetization event.

\section{Calpionellid events and magnetostratigraphy}

Correlation of calpionellid events with respect to magnetostratigraphy in previously studied coeval sections in the Carpathians in Slovakia (Houša et al., 1999; Grabowski et al., 2010b; Michalík et al., 2009, 
2016) and Poland (Grabowski and Pszczółkowski, 2006; Grabowski et al., 2013), in the Transdanubian Range in Hungary (Grabowski et al., 2010a), as well as in France (Wimbledon et al., 2013), Spain (Pruner et al., 2010), Italy (Houša et al., 1999; Channell and Grandesso, 1987) and Austria (Lukeneder et al., 2010) is shown in Table 1 and Fig. 3. Each calpionellid event exhibits different extent of dispersion. Even dispersed, the calpionellid events are restricted to one certain normal or reverse magnetic polarity chron. These are as follows (from top to bottom):

1. FO of Calpionella elliptica - within M17r;

2. FO of Remaneilla ferasini-M18n;

3. FOs of Tintinnopsella doliphormis and Calpionella minuta - also within M18n;

4. Acme of Crassicollaria parvula - M19n2n, below the Brodno subchron (M19n1r);

5. "explosion of Calpionella alpina" - M19n2n to M19n 1n (base of Berriasian);
6. FOs of Crassicollaria colomi and Crassicollaria brevis - lower half of M19n2n;

7. FOs of Calpionella grandalpina/Calpionella alpina - upper half of M20n to M19r;

8. FOs of Tintinnopsella carpathica/Tintinnopsella remanei - upper half of M20n, above or below the Kysuca subchron;

9. FO of Praetintinnopsella andrusovi - normally in M20n;

10. FO of Chitinoidella boneti - normally within M20r (base of upper Tithonian);

11. FO of Chitinoidellidae - M21r (the upper part of lower Tithonian).

\section{Calcareous nannofossil events and magnetostratigraphy}

The nannofossil events recognized in the Barlya section have been compared with previous nannofos-

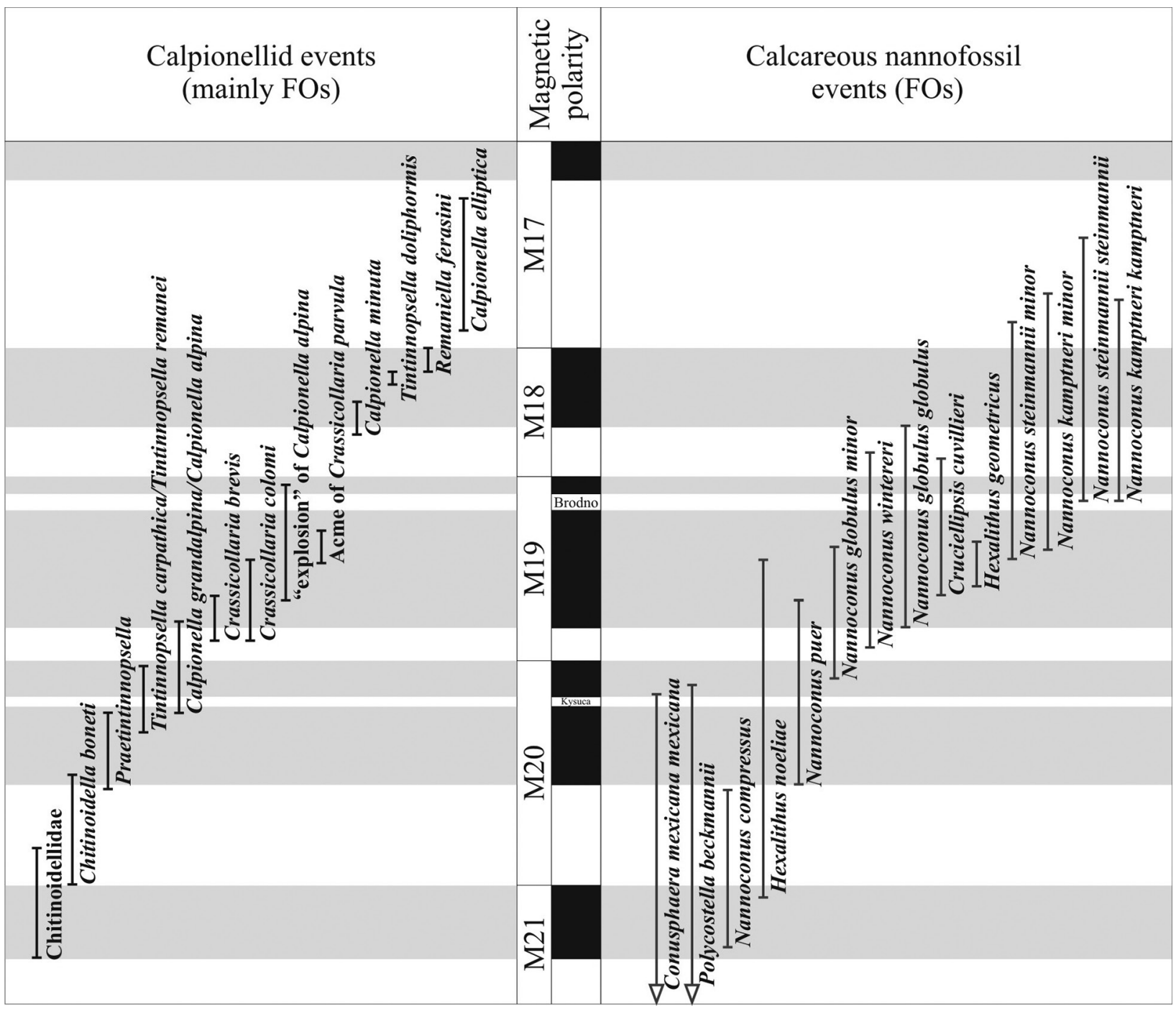

Fig. 3. Selected calpionellid and calcareous nannofossil events from the Tithonian/Berriasian boundary interval, directly correlated to magnetostratigraphy (for sources see references in Tables 1,2). 


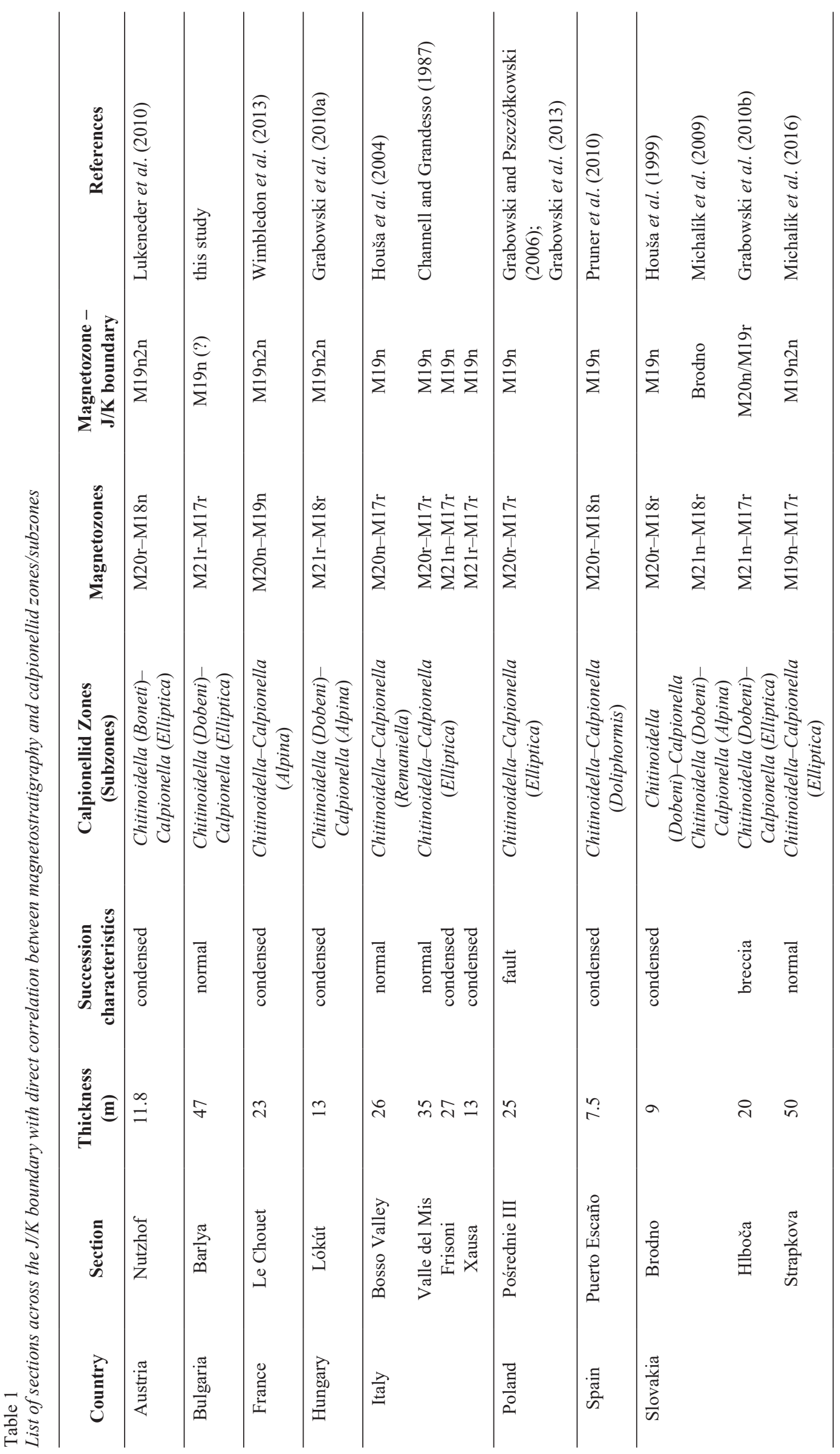




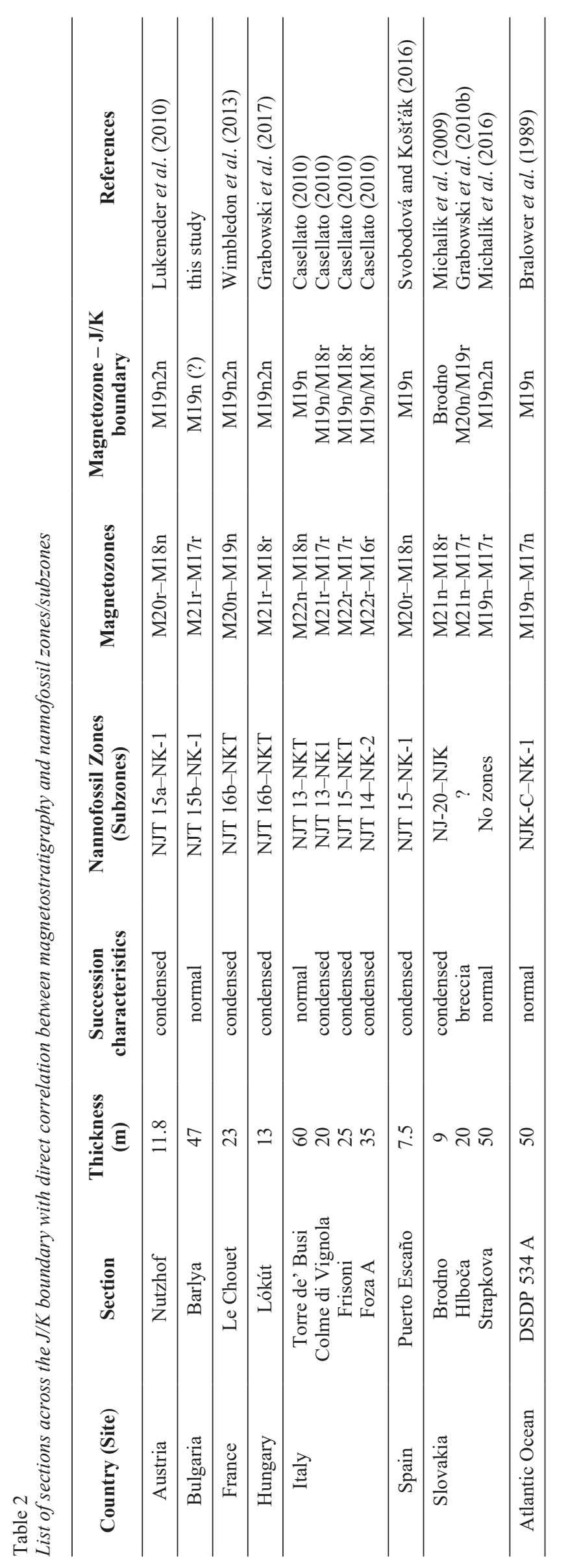


sil-magnetostratigraphy relationships mainly in Italy (Casellato, 2010; Channell et al., 2010), as well as in Spain (Svobodová and Košt'ák, 2016), Austria (Lukeneder et al., 2010), Slovakia (Michalík et al., 2009, 2016), France (Wimbledon et al., 2013) and Hungary (Grabowski et al., 2017) (see Table 2).

A comprehensive review of the available data on nannofossil and magnetostratigraphy correlation has clearly shown two distinct groups of nannofossil taxa: the first one, with rather scattered and diachronous FOs, and the second one, which displays more or less consistent FO record amongst different sections (Fig. 3). The first group includes Conusphaera mexicana mexicana, Polycostella beckmannii, Hexalithus noeliae and Nannoconus compressus. These taxa's FOs demonstrate diachroneity in the Tethyan realm, and therefore could hardly be used for precise correlation.

The second group includes Nannoconus globulus minor, Hexalithus geometricus, N. globulus globulus, N. wintereri, Cruciellipsis cuvillieri, N. steinmannii minor and N. kamptneri minor. Overall, their FOs fall within the long M19n chron. The FO of Hexalithus geometricus seems a fairly consistent bioevent at the middle of the M19n2n subchron and thus of potentially high relevance for detailed correlation(s). The FOs of N. steinmannii minor and N. kamptneri minor, commonly used for biostratigraphic zonation, appear concentrated within the upper part of the M19n and in the M18r chrons. It is worth noting that the next two evolving species in the early Berriasian, $N$. steinmannii steinmannii and $N$. kamptneri kamptneri, show relatively dispersed FOs within M19n1r-M17r chrons, which could be due to various reasons: preservation problems, problematic bio-magnetostratigraphy calibrations or simple diachroneity.

\section{CONCLUSIONS}

In the Barlya section (West Balkan Mts, Bulgaria), the direct correlation of magnetostratigraphy and microbiostratigraphy has revealed the presence of mag- netic polarity chrons from M21r to M17r in the upper Tithonian and lower Berriasian, as well as a number of correlative calpionellid and calcareous nannofossil events/biohorizons. A large interval of normal polarity between M20r and M17r appears to be partly remagnetized, and only two thin reversed intervals could be interpreted as remnants of M19r and M18r or Brodno. This large remagnetized interval extends from the base Boneti Subzone to the base Elliptica Subzone.

The calpionellid Chitinoidella, Praetintinnopsella, Crassicollaria and Calpionella zones and their subzones have been correlated to the magnetostratigraphy and to the calcareous nannofossil (sub)zones NJT 15b, NJT 16a, NJT 16b, NJT 17a, NJT 17b, NKT and NK1. The base of the Berriasian is traced at the base of the Calpionella alpina Subzone within nannofossil subzone NJT $17 \mathrm{~b}$.

A review of the available data of joint magnetoand biostratigraphy on calpionellids and calcareous nannofossils across the $\mathrm{J} / \mathrm{K}$ transition in the European Tethys shows here for the first time the extent of diachroneity of all major calpionellid and nannofossil events with respect to magnetostratigraphy. Thus, the main calpionellid events show dispersals in different sections within one certain normal or reversed magnetic polarity chron. The nannofossil events show grouping into two clusters: the first one is with considerable dispersal, and the second one is quite concentrated in restricted polarity chron interval, consistent and therefore recommendable for distant correlations.

\section{Acknowledgements}

The work on this publication has been supported by the Bulgarian Science Fund (contract DNTS Slovakia 01/9) and the Slovakian Research and Development Agency under the contract APVV-14-0118. Investigations of Jacek Grabowski and Kristalina Stoykova were financially supported by the project DEC-2011/03B/ ST10/05256 of the National Science Centre, Poland. Petr Schnabl was funded by Czech science foundation project no: 16-09979S.

\section{REFERENCES}

Benzaggagh, M., Cecca, F., Rouqet, I. 2010. Biostratigraphic distribution of ammonites and calpionellids in the Tithonian of the internal Prerif (Msila area, Morocco). Paläontologische Zeitschrift 84 (2), 301-315.

Bralower, T.J., Monechi, S., Thierstein, H.R., 1989. Calcareous nannofossil zonation of the Jurassic - Cretaceous boundary interval and correlation with with the geomagnetic polarity timescale. Marine Micropaleontology 14 (1-3), 153-235.

Casellato, C.E. 2010. Calcareous nannofossil biostratigraphy of Upper Callovian-Lower Berriasian successions from the
Southern Alps, North Italy. Rivista Italiana di Paleontologia e Stratigrafia 116 (3), 357-404.

Chadima, M., Hrouda, F. 2006. Remasoft 3.0 - a user-friendly paleomagnetic data browser and analyzer. Travaux Géophysiques $27,20-21$.

Channell, J.E.T., Grandesso, P. 1987. A revised correlation of Mesozoic polarity chrons and calpionellid zones. Earth and Planetary Science Letters 85 (1-3), 222-240.

Channell, J.E.T., Casellato, C.E., Muttoni, G., Erba, E. 2010. Magnetostratigraphy, nannofossil stratigraphy and appar- 
ent polar wander for Adria-Africa in the Jurassic-Cretaceous boundary interval. Palaeogeography, Palaeoclimatology, Palaeoecology 293, 51-75.

Grabowski, J. 2011. Magnetostratigraphy of the Jurassic/Cretaceous boundary interval in the Western Tethys and its correlation with other regions: a review. Volumina Jurassica 9, 105-128.

Grabowski, J., Pszczółkowski, A. 2006. Magneto- and biostratigraphy of the Tithonian-Berriasian pelagic sediments in the Tatra Mountains (central Western Carpathians, Poland): sedimentary and rock magnetic changes at the Jurassic/Cretaceous boundary. Cretaceous Research 27 (3), 398-417.

Grabowski, J., Haas, J., Márton, E., Pszczółkowski, A. 2010a. Magneto- and biostratigraphy of the Jurassic/Cretaceous boundary in the Lókút section (Transdanubian range, Hungary). Studia Geophysica et Geodaetica 54, 1-26.

Grabowski, J., Michalík, J., Pszczółkowski, A., Lintnerová, O. 2010b. Magneto-, and isotope stratigraphy around the Jurassic/Cretaceous boundary in the Vysoká Unit (Malé Karpaty Mountains, Slovakia): correlations and tectonic implications. Geologica Carpathica 61 (4), 309-326.

Grabowski, J., Haas, J., Stoykova, K., Wierzbowski, H., Brański, P. 2017. Environmental changes around Jurassic/ Cretaceous transition: New nannofossil, chemostratigraphic and stable isotope data from the Lókút section (Transdanubian range, Hungary). Sedimentary Geology 360, 54-72.

Grabowski, J., Lakova, I., Petrova, S., Stoykova, K., Ivanova, D., Wójcik-Tabol, P., Sobień, K., Schnabl, P. 2016. Palaeomagnetism and integrated stratigraphy of the Upper Berriasian hemipelagic succession in Barlya section Western Balkan, Bulgaria: Implications for lithogenic input and palaeoredox variations. Palaeogeography, Palaeoclimatology, Palaeoecology 461, 156-177.

Grabowski, J., Schnyder, J., Sobień, K., Koptíková, L., Krzemiński, L., Pszczółkowski, A., Hejnar, J., Schnabl, P. 2013. Magnetic susceptibility and spectral gamma logs in the Tithonian-Berriasian pelagic carbonates in the Tatra Mts (Western Carpathians, Poland): Palaeoenvironmental changes at the Jurassic/Cretaceous boundary. Cretaceous Research 43, 1-17.

Gradstein, F.M., Ogg, J.G., Schmitz, M., Ogg, G. (Eds). 2012. The Geological Time Scale 2012. Elsevier, Amsterdam, $1176 \mathrm{pp}$.

Houša, V., Krs, M., Krsová, M., Man, O., Pruner, P., Venhodová, D. 1999. High-resolution magnetostratigraphy and micropalaeontology across the $\mathrm{J} / \mathrm{K}$ boundary strata at Brodno near Žilina, western Slovakia: summary of results. Cretaceous Research 20, 699-717.

Houša, V., Krs, M., Man, O., Pruner, P., Venhodová, D., Cecca, F., Nardi, G., Piscitello, M. 2004. Combined magnetostratigraphic, palaeomagnetic and calpionellid investigations across the Jurassic/Cretaceous boundary strata in the Bosso Valley, Umbria, central Italy. Cretaceous Research 25, 771-785.

Iglesia Llanos, M.P., Kietzmann, D.A., Martinez, M.K., Palma, P.M. 2017. Magnetostratigraphy of the Upper JurassicLower Cretaceous from Argentina: implications for the J-K boundary in the Neuquén Basin. Cretaceous Research 70, 189-208.

Kietzmann, D.A. 2017. Chitinoidellids from the Early Tithonian-Early Valanginian Vaca Muerta Formation in the Northern Neuquén Basin, Argentina. Journal of South American Earth Sciences 76, 152-164.

Lakova, I., Petrova, S. 2013. Towards a standard Tithonian to Valanginian calpionellid zonation of the Tethyan Realm. Acta Geologica Polonica 63 (2), 201-221.

Lakova, I., Stoykova, K., Ivanova, D. 1999. Calpionellid, nannofossil and calcareous dinocyst bioevents and integrated biochronology of the Tithonian to Valangian in the Western Balkanides, Bulgaria. Geologica Carpathica 50 (2), 151-168.

Lukeneder, A., Halásová, E., Kroh, A., Mayrhofer, S., Pruner, P., Reháková, D., Schnabl, P., Sprovieri, M., Wagreich, M. 2010. High resolution stratigraphy of the Jurassic-Cretaceous boundary interval in the Gresten Klippenbelt (Austria). Geologica Carpathica 61 (5), 365-381.

Michalík, J., Reháková, D. 2011. Possible markers of the Juras$\mathrm{sic} /$ Cretaceous boundary in the Mediterranean Tethys: A review and state of art. Geoscience Frontiers 2 (4), 475-490.

Michalík, J., Reháková, D., Halásová, E., Lintnerová, O. 2009. The Brodno section - a potential regional stratotype of the Jurassic/Cretaceous boundary. Geologica Carpathica 60 (3), 213-232.

Michalík, J., Reháková, D., Grabowski, J., Lintnerová, O., Svobodová, A., Schlögl, J., Sobień, K., Schnabl, P. 2016. Stratigraphy, plankton communities, and magnetic proxies at the Jurassic/Cretaceous boundary in the Pieniny Klippen Belt (Western Carpathians, Slovakia). Geologica Carpathica 67 (4), 303-328.

Ogg, J.G., Hasenyager, R.W., Wimbledon, W.A., Channell, J.E.T., Bralower, T.J. 1991. Magnetostratigraphy of the Jurassic-Cretaceous boundary interval - Tethyan and English faunal realms. Cretaceous Research 12 (5), 455-482.

Pop, G. 1997. Tithonian to Hauterivian praecalpionellids and calpionellids: bioevents and biozones. Mineralia Slovaca 29 (4-5), 304-305.

Pruner, P., Houša, V., Olóriz, F. Košt'ák, M., Krs, M., Man, O., Schnabl, P., Venhodová, D., Tavera, J.M., Mazuch, M. 2010. High-resolution magnetostratigraphy and biostratigraphic zonation of the Jurassic/Cretaceous boundary strata in the Puerto Escaño section (southern Spain). Cretaceous Research 31 (2), 192-206.

Reháková, D., Michalík, J., 1997. Evolution and distribution of calpionellids - the most characteristic constituents of Lower Cretaceous Tethyan microplankton. Cretaceous Research 18 (3), 493-504.

Svobodová, A., Košták, M. 2016. Calcareous nannofossils of the Jurassic/Cretaceous boundary strata in the Puerto Escaño section (southern Spain) - biostratigraphy and palaeoecology. Geologica Carpathica 67 (3), 223-238.

Wimbledon, W.A.P., Reháková, D., Pszczółkowski, A., Casellato, C.E., Halásová, E., Frau, C., Bulot, L.G., Grabowski, J., Sobień, K., Pruner, P., Schnabl, P., Čížková, K. 2013. An account of the bio- and magnetostratigraphy of the Upper Tithonian-Lower Berriasian interval at Le Chouet, Drôme (SE France). Geologica Carpathica 64 (6), 437-460. 